\title{
THE COMPARATIVE VIEW IN LABOUR HISTORY
}

\author{
OLD AND NEW INTERPRETATIONS OF THE ENGLISH \\ AND GERMAN LABOUR MOVEMENTS BEFORE 1914
}

SUMMARY: Comparisons between the English and German labour movements have a long tradition in historiography. In Germany they were primarily discussed in the context of the "German Sonderweg", a debate which was opened in the 1920 s and continues in the $1980 \mathrm{~s}$. The article presented here analyzes the methodological problems of Sonderweg comparisons of labour history and confronts the major arguments with the results of empirical research. It concludes that many old Sonderweg arguments can not withstand this confrontation. Nevertheless, the article proposes that the debate should be continued, since empirical research focuses on new aspects and supports the diagnosis of two different paths of labour history.

\section{Introduction}

From its inception the enterprise of labour historiography has relied upon a comparative perspective. The labour movement turned out to be an international phenomenon, developing in all capitalist countries in parallel, but dissimilar ways. Inasmuch as national sections of the Workers' Internationals differed considerably in actual strategy and tactics, the movements' activists themselves drew international comparisons, and historians could not avoid doing so as well. Against this background, most activists and historians have long rejected Marx's and Engels's assessment that "modern subjection to capital, the same in England as in France, in America as in Germany, has stripped ... [the Proletarian] of every trace of national character". They emphasize instead the differences between the national movements. ${ }^{1}$

English and German labour movements before 1914 are the focus of our attention in this article. The typologies to be found in handbooks or survey articles diagnose at least the following differences. ${ }^{2}$ Firstly, the formation of

${ }^{1}$ Even those scholars who stress the similarities cannot avoid having to deal with the differences as well. See, for example, Die internationale Arbeiterbewegung. Fragen der Geschichte und Theorie, 6 vols (Moscow, 1980-85), 1, pp. 148ff. The quotation is from Karl Marx and Friedrich Engels, "The Communist Manifesto", in Arthur P. Mendel (ed.), Essential Works of Marxism (New York, 1961), p. 23.

${ }^{2}$ See, for example, Hans Mommsen, "Arbeiterbewegung", in C. D. Kernig (ed.), Sowjetsystem und demokratische Gesellschaft. Eine vergleichende Enzyklopädie, 6 vols 
the English labour movement began with the evolution of trade unionism. The Labour Party, founded only at the beginning of the twentieth century, was nothing but an adjunct of trade unionism. In the history of the German labour movement, beginning with the foundation of the Social Democratic Party in 1863, the chronological order and the points of emphasis were exactly the reverse.

Secondly, before 1914 the English labour movement was reformist and opportunist; the workers' main concerns were with bread and butter questions. Only with regard to technological innovations did trade unions seriously oppose capitalism. The German labour movement of this period was, on the contrary, welded together by a radical ideology, which was influenced, at least to a degree, by Marxism and revolutionary ideas of class struggle. Only inasmuch as technological innovations were welcomed by this ideology did the German labour movement accept capitalism.

Thirdly, the English labour movement was fragmented into a multitude of occupational, regional and local associations, many of these being confined to skilled workers, particularly to the so-called labour aristocracy. These associations were often informally organized and sometimes came into conflict with each other because their areas of recruitment and responsibilities overlapped. By contrast, the German labour movement was from the start open to unskilled as well as skilled workers, highly centralized and, in a bureaucratic manner, led by a professional staff. If there was sectionalism at all, it was ideologically based.

Fourthly, by and large, the English labour movement formed an integral part of civil society. Trade unionists relentlessly defended workers' particular interests, but they played by the rules of the game. They acknowledged the market as an arena in which to resolve economic disputes, and Parliament as an arena in which to resolve political conflicts. Productive cooperation with liberalism ("Lib-Lab coalitions") was possible in this context. The German labour movement was to a considerably higher degree opposed to both civil society and capitalism. Cooperation between Social

(Frankfurt etc., 1966-72), 1, pp. 273-313; Peter Nettl, "The German Social-Democratic Party 1890-1914 as a Political Model", Past and Present, 30 (1965), pp. 65-95; Walter Kendall, The Labour Movement in Europe (London, 1975), and Klaus von Beyme, Gewerkschaften und Arbeitsbeziehungen in kapitalistischen Ländern (Munich, 1977). For similar but older typologies see Selig Perlman, A Theory of the Labor Movement (New York, 1928, repr. Philadelphia, 1979); Adolf Sturmthal, Comparative Labor Movements. Ideological Roots and Institutional Development (Belmont, CA, 1972), and Werner Sombart's contributions to comparative labour historiography "Dennoch!' Aus Theorie und Geschichte der gewerkschaftlichen Arbeiterbewegung (Jena, 1900), pp. 30-45ff. [hereafter, 'Dennoch!'], Sozialismus und soziale Bewegung (Jena, 1919, 7th and revised ed.), pp. 211ff., and Der proletarische Sozialismus ("Marxismus") [=10th and revised ed. of Sozialismus und soziale Bewegung], 6 vols (Jena, 1924), 2, pp. 358ff. [hereafter, Der proletarische Sozialismus]. 
Democracy and liberalism was inconceivable, particularly since the labour movement maintained its own ghetto culture. As a matter of fact, the movement was excluded from civil society and relatively powerless.

These differences between the two countries' labour movements seem to be generally accepted in labour historiography. Thus, comparative research is primarily concerned with the questions "How do we explain the particular English and German features?" and "How do we relate them to the two countries' general history?".

Occasionally, those questions have been discussed by German (but hardly by British) ${ }^{3}$ historians from the late nineteenth century onwards; Lujo Brentano and Werner Sombart are the most prominent of these comparativists. But systematic empirical comparisons have been carried out only from the early 1980s, after two British scholars, David Blackbourn and Geoff Eley, opened an influential controversy about the so-called Deutscher Sonderweg. ${ }^{4}$ This concept, which claims that Germany followed a different path from other Western European countries into the twentieth century, had first been developed in the 1920s and, with some shifts of emphasis, was revived from the 1960s and 1970s onwards. It primarily focuses on the question "What were the historical roots of National Socialism?". But, since the relatively weak position in politics and society of the German labour movement is discussed as one among numerous other answers to this question, Sonderweg historians deal with the history of the German labour movement as well. ${ }^{5}$

The Sonderweg concept is based on abstract arguments and not made to measure for labour historiography. Therefore, it was easy for empirical labour research of the last decade to criticize it. Comparative studies, many of them motivated by the Sonderweg debate,${ }^{6}$ have made a considerable

${ }^{3}$ An example is G. D. H. Cole, The World of Labour, A Discussion of the Present and Future of Trade Unionism (London, 1919, 4th ed.; repr. Brighton, 1973), pp. 169ff. For possible reasons for the relative lack of British contributions see Perry Anderson, "Components of the National Culture", New Left Review, 50 (1968), pp. 3-20.

${ }^{4}$ David Blackbourn and Geoff Eley, Mythen deutscher Geschichtsschreibung. Die gescheiterte bürgerliche Revolution von 1848 (Frankfurt etc., 1980) [hereafter, Mythen deutscher Geschichtsschreibung]; for a revised English translation see the authors' The Peculiarities of German History. Bourgeois Society and Politics in Nineteenth-Century Germany (Oxford, 1984).

"Cf. Helga Grebing, Der "deutsche Sonderweg" in Europa 1806-1945. Eine Kritik (Stuttgart etc., 1986), pp. 118ff., and Klaus Tenfelde, "Geschichte der deutschen Arbeiter und der Arbeiterbewegung - ein Sonderweg", in Der Aquäduct 1763-1988. Ein Almanach aus dem Verlag C. H. Beck im 225. Jahr seines Bestehens (Munich, 1988), pp. $469-483$.

${ }^{6}$ See particularly the volumes edited by Jürgen Kocka: Europäische Arbeiterbewegungen im 19. Jahrhundert. Deutschland, Osterreich, England und Frankreich im Vergleich (Göttingen, 1983) [hereafter, Europäische Arbeiterbewegungen], and Arbeiter und Bürger im 19. Jahrhundert. Varianten ihres Verhältnisses im europäischen Vergleich (Mu- 
contribution to this general attack. It was so successful that for the present it seems fashionable among historians to explicitly dissociate themselves from the concept. However, before the Sonderweg thesis is finally buried, this article will revive it as a central theme. To sharpen and differentiate the argument, it starts by fleshing out the Sonderweg interpretation of German labour history and then contrasts the main arguments with critical assessments and alternative analyses of recent comparative studies. In addition, it revives some older, almost forgotten studies that do not agree with the concept either. Finally, to avoid mere negative criticism and to meet the Sonderweg level of analysis, the present article tries to relate the alternative explanations of English and German labour history to the general history of the two countries.

\section{The Sonderweg interpretation of labour history}

The debate about the German Sonderweg began in the 1920s and has been enjoying something of a revival since the late 1960s. Although the contributors belonged to various generations, represented a broad political spectrum, and were involved in quite different scientific discourses, their analyses of the German labour movement were basically similar. As a central theme they did not pick out the labour movement itself but its functions in the political structure of civil society. And, although they observed German history from different political points of view, most of them, as their distinguishing characteristic, explicitly or implicitly compared it with the "English model". Thus they considered the development of an independent working-class party - in a celebrated phrase by Gustav Mayer "the separation of proletarian from liberal democracy" - as the crucial problem; in particular, they were concerned with its relatively early occurrence.

Conservative intellectuals such as Oswald Spengler and Gerhard Ritter, who dominated the Sonderweg debate in the 1920s, were in any case opposed to the entry into politics of "the masses" and, in addition, regarded Social Democracy's ideology as being influenced by French ideology, in other words, by the thought of Germany's major foreign enemy. They were

nich, 1986) [hereafter, Arbeiter und Bürger]; also see Klaus Tenfelde (ed.), Arbeiter und Arbeiterbewegung im Vergleich. Berichte zur internationalen historischen Forschung (Munich, 1988) [hereafter, Arbeiter und Arbeiterbewegung], and Wolfgang J. Mommsen and Hans-Gerhard Husung (eds.), Auf dem Wege zur Massengewerkschaft. Die Entwicklung der Gewerkschaften in Deutschland und Großbritannien 1880-1914 (Stuttgart, 1984) [hereafter, Auf dem Wege zur Massengewerkschaft].

7 This is the title of a famous article by Gustav Mayer, "Die Trennung der proletarischen von der bürgerlichen Demokratie in Deutschland 1863-1870", in Hans-Ulrich Wehler (ed.), Radikalismus, Sozialismus und bürgerliche Demokratie (Frankfurt, 1969), pp. 108-178 [hereafter, Radikalismus, Sozialismus und bürgerliche Demokratie]. 
firmly convinced that, in contrast to England and other European countries, the German state and its bureaucracy should have been capable of solving the "social question" by their own means if the German working class had not acted so "rashly" and "covetously". In the context of the post-World-War-I political climate in Germany, this argument was well suited to strengthening the reactionary Dolchstoßlegende (myth of the stab in the back), which held the Social Democrats responsible for the military defeat and the destruction of the Kaiserreich in the revolution of 1918-19. ${ }^{8}$

A small number of liberal and social-democratic historians joining the debate in this period, for example Hermann Oncken, Erich Eyck, and Gustav Mayer also considered the foundation of Social Democracy in 1863 as harmful. However, they were less concerned with the state than with the bourgeoisie and the middle classes. They developed the argument that an independent working-class party rising at all, or - compared with England rising "too early", had distracted the middle classes from their efforts to finally restrain the aristocracy and to rid Germany's social and political life of its feudal relics. The middle classes' fear of socialism was considered to be a primary reason for the failure to break up the authoritarian power structure of the German Kaiserreich in a peaceful manner. ${ }^{9}$

A similar assessment was presented by a younger generation of Sonderweg historians from West Germany such as Hans Mommsen, Gerhard A. Ritter, Werner Conze, Wolfgang Schieder, and Jürgen Kocka in the period between the late 1960 s and the early 1980 s. $^{10}$ The Godesberger

${ }^{8}$ See, for example, Oswald Spengler, Preußentum und Sozialismus (Munich, 1921). For a survey of this discussion see Bernd Faulenbach, Ideologie des deutschen Weges. Die deutsche Geschichte in der Historiographie zwischen Kaiserreich und Nationalsozialismus (Munich, 1980), pp. 104-108, 163ff. [hereafter, Ideologie des deutschen Weges].

${ }^{9}$ These liberal historians can also be regarded as the initiators of the Sonderweg arguments with respect to the labour movement before 1914. Mayer's most important articles are collected in Radikalismus, Sozialismus und bürgerliche Demokratie and in Hans-Ulrich Wehler (ed.), Arbeiterbewegung und Obrigkeitsstaat (Bonn-Bad Godesberg, 1972); also see Erich Eyck, Der Vereinstag deutscher Arbeitervereine 1863-1868. Ein Beitrag zur Entstehung der deutschen Arbeiterbewegung (Berlin, 1904), pp. 94-102. The main arguments are summarized in Faulenbach, Ideologie des deutschen Weges, p. 103.

${ }_{10}$ See, for example, the articles in Hans Mommsen (ed.), Sozialdemokratie zwischen Klassenbewegung und Volkspartei (Frankfurt, 1974); also see Gerhard A. Ritter, Arbeiterbewegung, Parteien und Parlamentarismus. Aufsätze zur deutschen Sozial- und Verfassungsgeschichte des 19. und 20. Jahrhunderts (Göttingen, 1976) [hereafter, Arbeiterbewegung, Parteien und Parlamentarismus]; Werner Conze and Dieter Groh, Die Arbeiterbewegung in der nationalen Bewegung. Die deutsche Sozialdemokratie vor, während und nach der Reichsgründung (Stuttgart, 1966); Jürgen Kocka, Lohnarbeit und Klassenbildung. Arbeiter und Arbeiterbewegung in Deutschland 1800-1875 (Berlin, 1983) [hereafter, Lohnarbeit und Klassenbildung], and "Die Trennung von bürgerlicher und proletarischer Demokratie im europäischen Vergleich. Fragestellungen und Ergebnisse", in Kocka (ed.), Europäische Arbeiterbewegungen, pp. 5-20 [hereafter, "Die Trennung von bürgerlicher und proletarischer Demokratie"]. 
Programm of the Social Democratic Party (1959) and the party's coalitions with the Christian Democrats and the Liberals (1966-1982) confirmed them in their conviction that, in principle, an alliance between the middle and the working classes would have been possible in nineteenth-century Germany, as it was in England. ${ }^{11}$ But, in contrast to the liberal view of the 1920 s, Sonderweg analyses of this period made it perfectly clear that they considered the failure of such an alliance not only a consequence of working-class radicalism but of the middle classes' indifference towards working-class affairs as well. ${ }^{12}$

Just as Sonderweg historians of the 1920 s, the 1960 s and after agreed about the diagnosis and, in principle, about a negative assessment of the German labour movement's development, they presented similar explanations about its origins and particularities. In the introduction to the revised 1920 edition of his Lassalle biography, Hermann Oncken emphasized a "double problem" of German history: around the middle of the nineteenth century, the industrial revolution emerged, bringing in its wake qualitatively new social problems, while the formation of the nation state was still incomplete. In this constellation, liberal and conservative politicians played national interests off against the working classes' interests in democracy and social reform. According to Oncken, the result was an intensification of social conflicts which did not find parallels in contemporary England, or in other Western European countries. Since the formation of the nation state in these countries had long been accomplished when industrialization started, they could separate those problems from each other and solve them, one after the other - to the benefit of both national interests and the working class. ${ }^{13}$

The same type of explanation was offered by Sonderweg historians of the $1960 \mathrm{~s}-1980$ s. But it now no longer had the status of an isolated ad hoc argument, for it was introduced as a component of a more comprehensive interpretative framework. This framework was derived from modernization theory, a theory borrowed from American sociologists. ${ }^{14}$ It included

${ }^{11}$ The influence of this political context is also diagnosed by Geoff Eley, "Joining two Histories: the SPD and the German Working Class, 1860-1914", in Geoff Eley (ed.), From Unification to Nazism. Reinterpreting the German Past (Boston, 1986), pp. 117f. ${ }^{12}$ The title of Gustav Mayer's famous article "The Separation of Proletarian from Liberal Democracy in Germany" (1912) was revised; the second generation of Sonderweg historians diagnosed a separation of proletarian and liberal democracy and called both parties to account. See Kocka, "Die Trennung von bürgerlicher und proletarischer Demokratie". This alteration was preceded by Hans-Ulrich Wehler's "Nachwort" in Mayer, Radikalismus, Sozialismus und bürgerliche Demokratie, pp. 191ff.

${ }^{13}$ Hermann Oncken, Lassalle. Eine politische Biographie (Stuttgart and Berlin, 1920, 3rd ed.), pp. 1ff. For similar arguments presented in this period see Faulenbach, Ideologie des deutschen Weges, p. 358, note 122.

${ }^{14}$ For an overview see Hans-Ulrich Wehler, Modernisierungstheorie und Geschichte (Göttingen, 1975). 
Alexander Gerschenkron's analysis of the industrialization of relatively backward societies as well as considerations about other so-called "modernization crises" which in Germany had developed from the middle of the nineteenth century onwards and, according to Sonderweg historians, reinforced each other: the establishment of a constitution for the Deutsche Reich, founded "with blood and iron" in 1871; the development of a political-party system on a national basis; the introduction of universal suffrage for men as a major step towards political mass-mobilization.

Sonderweg historians considered these "modernization crises" to be particularly complex and problematic in Germany since they arose in a society which in other respects was still shaped by strong pre-modern traditions. Compared with the English Parliament, the authority of the German Reichstag appeared rather limited, and the bureaucracy had preserved its traditional power and influence. The upper bourgeoisie was thought to have accepted the political and social dominance of the aristocracy. And the petty bourgeoisie's impulses for modernization and democratization were considered weak anyway, since most self-employed artisans and shopkeepers remained committed to the guild system. Hans-Ulrich Wehler's influential interpretation of the German Kaiserreich, first published in 1973, stressed its ambiguous character. On the one hand, he presented German history from 1871 to 1914 as a model for highly successful socio-economic modernization, the rise of the labour movement being a part of this development. On the other hand, with respect to decisive power relations and political culture, he draws a picture of a backward and virtually static state of affairs. ${ }^{15}$

Historians who try to apply the Sonderweg concept to the analysis of the English and German labour movements before 1914 face several problems, many of them resulting from the fact that Sonderweg arguments had basically been conceived long before labour historiography became a more widely practiced discipline. Thus if historians use it unreflectively and without changes, they find themselves enmeshed in a set of assumptions about the relationship between the working class and society that do not accord with the latest research. A fundamental Sonderweg argument is, for example, based on the doubtful frustration/aggression hypothesis: the more modernization crises accumulate, the more workers are likely to react with political radicalism. ${ }^{16}$ And the concept is pessimistic: it one-sidedly

${ }^{15}$ See Hans-Ulrich Wehler, Das Deutsche Kaiserreich (Göttingen, 1973). For a detailed overview of the relevant literature see Jürgen Kocka, "German History before Hitler: The Debate about the German Sonderweg", Journal of Contemporary History, XXIII (1986), pp. 4-6.

${ }^{16}$ For an empirical critique of the argument as it is used in the general context of the 
presents pre-industrial traditions as shackles, and does not take into consideration the fact that they can just as well be advantageous for the labour movement, as E. P. Thompson has demonstrated in The Making of the English Working Class. ${ }^{17}$

However, the concept focuses on several factors of German history that have rightly been taken seriously by comparative research on labour history: the comparatively early rise of a working-class political party, the attitudes of the liberal middle classes towards labour, the constitution, the backward, then accelerating economic development, and the social impact of pre-industrial traditions on the shaping of the labour movement. The following sections discuss these factors in greater detail.

\section{The Sonderweg interpretation and empirical comparative research}

\section{The "premature" rise of Social Democracy}

The Sonderweg approach one-sidedly observes English history from the German point of view. This is not a problem in principle, as many critics of the concept suggest who point to the fact that each country's history is exceptional. ${ }^{18}$ Comparisons need a common point of reference in order to analyze two or several cases, and there is no a priori reason why it should not be constructed from a particular country's point of view. ${ }^{19}$ But in the case of comparative labour historiography the German view turns out to be problematic. It biases the concept in favour of a synchronous analysis of the two countries' movements and, thereby, tends to transfer the caesura of the backward German to the English pioneer movement. Historians have meanwhile begun to discuss the questionability of the synchronous approach,$^{20}$ and some empirical studies have taken this methodological prob-

Sonderweg debate, see M. Rainer Lepsius, "Parteiensystem und Sozialstruktur: zum Problem der Demokratisierung der deutschen Gesellschaft", in Gerhard A. Ritter (ed.), Deutsche Parteien vor 1918 (Cologne, 1973), pp. 59f. and the literature quoted there.

${ }^{17}$ E. P. Thompson, The Making of the English Working Class (London, 1963). Also see the arguments in Albert O. Hirschman, "Rival Interpretations of Market Society: Civilizing, Destructive, or Feeble?", Journal of Economic Literature, XX (1982), pp. 1463-1484.

${ }_{18}$ See, for example, Blackbourn and Eley, Mythen deutscher Geschichtsschreibung, p. 81.

19 See Adam Przeworski and Henry Teune, The Logic of Comparative Social Inquiry (New York, 1970), p. 10.

${ }^{20}$ See the debate between John Breuilly and Gerhard A. Ritter in Kocka, Arbeiter und Bürger, pp. 290, 322; Eric Hobsbawm, "Der New Unionism - Eine komparative Betrachtung", in Mommsen and Husung, Auf dem Wege zur Massengewerkschaft, pp. 19ff. 
lem into account. As a consequence, the picture of many contrasts outlined in the introduction to this article has had to be corrected in several respects.

A first correction significant for the interpretation of German Social Democracy results from comparative research on early trade unionism. The relative backwardness of the German trade-union movement became the centre of attention after detailed studies of the early phase of English trade unionism had led to the result that the time-lag between the two countries' movements was considerably more pronounced than historians had previously realized. It covered more than 150 years and could not simply be explained by the backwardness of industrialization in Germany: while the English movement had its origins as far back as the early eighteenth century and could be regarded as relatively "mature" from about 1875 , German trade unions developed slowly, with few exceptions, from the 1860 s and made a breakthrough only from the 1890 s onwards.$^{21}$ In full knowledge of this time-lag, which is attributed to state intervention and the survival of the guild system in Germany, the predominance of the political labour movement in nineteenth-century Germany appears to be considerably overstated and misinterpreted by the Sonderweg concept. It should not be regarded as an indication of the German working class's particular preference for politics, but first of all, as the logical consequence of its inability to organize trade unions in the eighteenth and early nineteenth centuries. ${ }^{22}$

This view is supported by comparative studies of the early phase of both countries' political labour movements, some of them being of recent origin, others, written by Lujo Brentano, Adolf Held and the social-democratic party historian Hermann Schlüter, dating from the late nineteenth century. While Sonderweg historians contrasted the rise of German Social Democracy in the 1860s with the English Reform Movement of the same period, these historians compare it with Chartism, England's first political labour movement rising in the early 1830 s and going into decline about the middle of the nineteenth century. ${ }^{23}$ They argue that both early Social Democracy

${ }^{21}$ See C. R. Dobson, Masters and Journeymen. A Prehistory of Industrial Relations 1717-1800 (London, 1980); John Rule, The Experience of Labour in Eighteenth-Century Industry (London, 1981). For a statistical overview of German backwardness at the end of the nineteenth century see Marc Linder, European Labor Aristocracies: Trade Unionism, the Hierarchy of Skill, and the Stratification of the Manual Working Class before the First World War (Frankfurt and New York, 1985), pp. 191ff. [hereafter, European Labor Aristocracies].

${ }^{22}$ This is the argument of my book Deutsche und englische Gewerkschaften. Entstehung und Entwicklung bis 1878 im Vergleich (Göttingen, 1986) [hereafter, Deutsche und englische Gewerkschaften].

${ }^{23}$ For the following argument see Lujo Brentano, "Die englische Chartistenbewegung", Preußische Jahrbücher, XXXIII (1874), pp. 431-447, 531-550; Adolf Held, "Der englische Chartismus und die deutsche Socialdemokratie", Concordia. Zeitschrift für die 
and Chartism were young and inexperienced movements while the Reform Movement, which closely cooperated with Liberalism, was supported by a relatively mature working class. From this point of view they reveal striking similarities between the two countries' pioneer movements and describe Chartism as a predecessor of early Social Democracy, particularly of Lassalle's Allgemeiner Deutscher Arbeiterverein founded in 1863. For example, scholars point to the fact that the main political issue pushed by Chartism as well as by Lassalle's party was universal suffrage. When the English middle classes stopped supporting the working class on this issue after the 1832 Reform Act had fulfilled their own political goals, England's political climate was for almost twenty years marked by the same "separation of proletarian from bourgeois democracy" that Sonderweg historians had diagnosed with respect ot German history from the 1860 s onwards. Even the ideology and rhetoric of both movements turned out to be similar, particularly since major Chartist arguments seem to have been adopted by the German movement. ${ }^{24}$

Thus by detailed research on the formative phase of the two countries' labour movements, diachronic comparisons qualify the general Sonderweg diagnosis that in the nineteenth century there was an English type of labour movement dominated by bread-and-butter problems and a German type dominated by political issues. The crucial problems that remain to be explained are the decline of the English independent political labour movement from the middle of the nineteenth century onwards and the stability of German Social Democracy as a political party. ${ }^{25}$

Arbeiterfrage (1875), pp. 47, 50, 58, 63ff., and Hermann Schlüter, Die ChartistenBewegung. Ein Beitrag zur sozialpolitischen Geschichte Englands (New York, 1916) [hereafter, Die Chartisten-Bewegung). For more recent analyses see Sidney Pollard, "England: Der unrevolutionäre Pionier", in Kocka, Europäische Arbeiterbewegungen, pp. 21-38 [hereafter, "Der unrevolutionäre Pionier"]; Christiane Eisenberg, "Chartismus und Allgemeiner Deutscher Arbeiterverein. Die Entstehung des politischen Arbeiterbewegung in England und Deutschland", in Arno Herzig and Günter Trautmann (eds), "Der kühnen Bahn nun folgen wir . .." Ursprünge, Erfolge und Grenzen der Arbeiterbewegung in Deutschland, 6 vols (Hamburg, 1989), 1, pp. 151-170 [hereafter, "Chartismus und Allgemeiner Deutscher Arbeiterverein"].

${ }^{24}$ For examples, see Schlüter, Die Chartisten-Bewegung, and Eisenberg, "Chartismus und Allgemeiner Deutscher Arbeiterverein".

${ }^{25}$ This was the focus of Werner Sombart's comparative research, too. See his Sozialismus und soziale Bewegung, p. 215: "[W]ie erklärt sich diese eigenartige Entwicklung Englands, wie erklärt sich der Sondergang, den die soziale Bewegung dort nimmt, erklärt sich vor allem auch das Fehlen jeder bewußt sozialistischen Note, nachdem doch kein Proletariat so nahe einer revolutionär-sozialistischen Bewegung gestanden hatte, wie das englische in der Chartistenbewegung." 


\section{The attitude of the liberal middle classes towards labour}

Along with recent empirical research on the middle classes and liberalism, these corrections of the Sonderweg interpretation have led to a reevaluation of the Lib-Lab coalitions of the 1860s, that were an English, not a German experience. According to comparative studies by John Breuilly, Shulamit Volkov and Jürgen Reulecke this English/German difference cannot be explained with reference to a particular lack of interest of the German middle classes towards labour, as argued from the Sonderweg standpoint. These authors concede that Germany lacked a counterpart to the most radical middle-class groups such as the Christian Socialists or the Positivists who joined the English working class on such issues as franchise reform or legal reforms in favour of trade unionism and cooperative shopkeeping. ${ }^{26}$ However, they do not blame the German Bürgertum for an uncommon lack of interest in labour. Breuilly points to the fact that " 19 th century liberals were generally hostile to universal manhood suffrage even if they were usually opposed to any franchise based on personal privilege or membership of corporations". ${ }^{27}$ Volkov reveals striking similarities between administrators' and employers' motives in supporting the repeal of the Combination Acts in England (1824-25) and in Germany (1869). ${ }^{28}$ And Reulecke demonstrates that, at the local level, the middle-class commitment to voluntary social work was in Germany even more pronounced than in England. ${ }^{29}$ With respect to the later nineteenth and early twentieth centuries further similarities between the attitudes of English and German social liberals have been revealed by Gustav Schmidt. ${ }^{30}$

Against the background of these results the different degrees of cooperation between the two countries' middle and working classes have to be explained differently. One possible starting point is the earlier origins of the English labour movement, something which is emphasized by diachronic comparisons. According to Sidney Pollard and other British historians the

${ }^{26}$ See John Breuilly, "Civil Society and the Labour Movement, Class Relations and the Law. A Comparison between Germany and England", in Kocka, Arbeiter und Bürger, p. $307 \mathrm{ff}$. [hereafter, "Civil Society and the Labour Movement"].

27 Ibid., p. 289.

${ }^{28}$ Shulamit Volkov, "Enactment and Repeal of Combination Acts: England and Prussia Compared", Tel Aviver Jahrbuch für deutsche Geschichte, IX (1980), p. 327. Also see Breuilly, "Civil Society and the Labour Movement", p. 310, who rightly points to the similarities of the views of Francis Place and Hermann Schulze-Delitzsch, the central figures in the two countries' campaigns against the combination laws.

${ }^{29}$ Jürgen Reulecke, "Formen bürgerlich-sozialen Engagements in Deutschland und England im 19. Jahrhundert", in Kocka, Arbeiter und Bürger, pp. 261-286 [hereafter, "Formen bürgerlich-sozialen Engagements"].

${ }^{30}$ Gustav Schmidt, "Liberalismus und soziale Reform: Der deutsche und der britische Fall”, Tel Aviver Jahrbuch für deutsche Geschichte, XVI (1987), pp. 177-199. 
relatively amicable relations between the classes in late nineteenth-century England are mainly a result of the Chartist experience that had taught a lesson to both the working and the middle classes. After the decline of Chartism, the English working class hesitated to initiate a new political movement and concentrated its collective activities on trade unionism and cooperative shopkeeping. The middle classes, on the other hand, were now ready to cooperate since they were eager to avoid a revival of working-class radicalism. ${ }^{31}$

A similar argument has been developed by comparative trade-union historiography. Several authors reject the Sonderweg assumption that authoritarian paternalism (Herr im Haus-Ideologie) was a peculiarity of German employers; ${ }^{32}$ incidentally, neither do they consider it a "feudal relic". According to their empirical evidence English employers were, in principle, paternalistic and authoritarian as well. However, facing well-organized and powerful trade unions, at least from the middle of the nineteenth century onwards, they could not afford to realize their politics of obstruction to the same degree as their German competitors. As a result, before 1914 wage agreements were a common feature of English, but not of German, industrial relations. ${ }^{33}$

An international and interdisciplinary research group studying the nineteenth-century European bourgeoisie has recently published its reports, which have indirectly contributed to supporting these arguments. The group's comparative studies in the history of middle-class formation led to the conclusion that there was a parallel process of development in England and Germany. Both countries' middle classes rose slowly and steadily from the eighteenth century to the 1840 s; they both reached their highest degree of coherence between the 1840s and 1870s; and from then on began to lose their relative exclusiveness. ${ }^{34}$ This parallelism reflects the particular prob-

${ }^{31}$ This is, for example, the interpretation of Pollard, "Der unrevolutionäre Pionier".

${ }^{32}$ This view goes back to Gerhard von Schulze-Gaevernitz, Zum sozialen Frieden. Eine Darstellung der sozialpolitischen Erziehung des englischen Volkes im neunzehnten Jahrhundert, 2 vols (Leipzig, 1890); English translation: Social Peace. A Study of the Trade Union Movement in England (London, 1893).

${ }^{33}$ See Dick Geary, "Arbeiter und Unternehmer in deutschen Kaiserreich", in Werner Abelshauser (ed.), Konflikt und Kooperation. Strategien europäischer Gewerkschaften im 20. Jahrhundert (Essen, 1988), pp. 173ff., and Eisenberg, Deutsche und englische Gewerkschaften, pp. 234-248. Also see Jutta Rabenschlag-Kräußlich, Parität statt Klassenkampf? Zur Organisation des Arbeitsmarktes und Domestizierung des Arbeitskampfes in Deutschland und England 1900-1918 (Frankfurt and Bern, 1983), and Joachim Rückert and Wolfgang Friedrich, Betriebliche Arbeiterausschüsse in Deutschland, Großbritannien und Frankreich im späten 19. und frühen 20. Jahrhundert. Eine vergleichende Studie zur Entwicklung des kollektiven Arbeitsrechts (Frankfurt, 1979).

${ }^{34}$ See Jürgen Kocka (ed.), Bürgertum im 19. Jahrhundert. Deutschland im europäischen Vergleich, 3 vols (Munich, 1988) [hereafter, Bürgertum im 19. Jahrhundert]; see in particular Kocka's introductory summary "Bürgertum und bürgerliche Gesellschaft im 
lems of the English middle classes in forming themselves into a class; for example, the strong social position of the aristocracy and the cleft between the financial and the industrial bourgeoisies. This result of the research group is worth mentioning for it points to the observation that relations between the working and the middle classes developed in both countries on the basis of completely different preconditions. While in England the formation of the two classes proceeded simultaneously, in Germany the labour movement rose only after the formation of the Bürgertum had already been accomplished. From this point of view, it appears that the disturbances of class relations in Germany did not result from the coincidence that Social Democracy and trade unionism rose "too early", as Sonderweg historians used to argue, but from their relative delay. ${ }^{35}$

\section{The constitution}

With respect to the German Kaiserreich, Sonderweg historians have emphasized that German Members of Parliament, knowing that the Reichstag was stripped of a main function of the English Parliament, i.e. of the power to decide the formation of the government, were less ready to compromise on single issues than their English counterparts. While the English not only formulated compromises but also presented them to the voters, the decisions of the German electorate remained strictly related to party programmes, ideologies and world views. ${ }^{36}$

This argument may be true with respect to the late nineteenth and early twentieth centuries, but it can hardly be applied to the formative phase of the two countries' labour movements. Until the $1870 \mathrm{~s}$, in both countries they were either not represented in parliament at all, or their representatives were few and relatively powerless. Thus English and German working-class MPs had hardly any opportunity to demonstrate their willingness to cooperate. Nevertheless England experienced Lib-Lab coalitions while Germany did not.

Another Sonderweg argument is more suited as a general explanation of the English/German differences mentioned above. It refers to the long

19. Jahrhundert. Europäische Entwicklungen und deutsche Eigenarten", in vol. 1,p. 57, and Eric Hobsbawm's contribution "Die englische middle-class 1780-1920", in vol. 1, pp. 102-106.

${ }^{35}$ I have elaborated the same argument in two other contexts: "Arbeiter, Bürger und der 'bürgerliche Verein' 1820-1870. Deutschland und England im Vergleich", in Kocka, Bürgertum im 19. Jahrhundert, 2, pp. 187-219 [hereafter, "Arbeiter, Bürger und der 'bürgerliche Verein' "]; and Deutsche und englische Gewerkschaften, pp. 255-263.

${ }^{36} \mathrm{See}$, for example, Kurt Kluxen, "Britischer und deutscher Parlamentarismus im Zeitalter der industriellen Massengesellschaft - Ein verfassungsgeschichtlicher Vergleich", in Adolf M. Birke and Kurt Kluxen (eds), Deutscher und Britischer Parlamentarismus. British and German Parliamentarism (Munich etc., 1985), pp. 38ff. 
tradition of parliamentarianism in England which is considered to act as a common bond between the middle and working classes. By contrast, the absence of this tradition in Germany is regarded as a burden for the two classes' relationships with each other.$^{37}$ Indeed, this is not a weak argument. In the nineteenth century hardly any Englishman or woman denied that parliament was the repository of the liberties of the people, and this belief was not only strengthened by parliamentarianism itself but also, as Ross McKibbin has argued, by "the introduction into political discourse of metaphors borrowed from sport, a passion common to all classes - 'fair play' ... 'below the belt' ... etc. - [that] made a breach of the rule unthinkable". ${ }^{38}$

However, emphasizing the experience of Chartism, recent comparative analyses have led to the conclusion that parliamentarianism was perhaps a necessary, but not a sufficient, prerequisite for fruitful cooperation between the middle and working classes. According to Sidney Pollard and other scholars, the readiness of the English working class to cooperate was, in the later nineteenth and early twentieth centuries, less a result of parliamentarianism itself than of its English concomitant, the two-party system. ${ }^{39}$ It made the foundation of a third, working-class, party more difficult and less promising than in contemporary Germany, and led the working class to accept the rules of pressure-group politics, a rationale that was particularly accepted after the decline of Chartism. Thus, from the 1860 s onwards, English trade unions successfully used tactics of "rewarding their friends and punishing their enemies". ${ }^{40}$

According to this line of argument, the readiness of the middle classes to cooperate was no direct consequence of parliamentarianism either, but of the restricted English franchise. While universal suffrage for men was, with respect to the elections for the German Reichstag, granted to the German working class as early as 1871 (and in the North German Confederation as

${ }^{37}$ Already in the 1920s Werner Sombart emphasized that the English Parliament looked back to a long tradition at the time of the formation of the political party system, while, in Germany, political parties were generally older than the constitution of the Kaiserreich. As a result, German parties, according to Sombart, lacked the common political basis of the English. See Sombart, Der proletarische Sozialismus, 2, p. 368. Also see Gerhard A. Ritter, "Entwicklungsprobleme des deutschen Parlamentarismus", in Arbeiterbewegung, Parteien und Parlamentarismus, p. 170.

${ }_{38}$ Ross McKibbin, "Why is there no Marxism in Great Britain?", English Historical Review, IC (1984), p. 314 [hereafter, "Why is there no Marxism?"].

${ }^{39}$ Pollard, "Der unrevolutionäre Pionier", pp. 33f.; also see Sombart, "Dennoch!", p. 37 and the position of Bismarck, summarized by Reinhard J. Lamer, Der englische Parlamentarismus in der deutschen politischen Theorie im Zeitalter Bismarcks (18571890). Ein Beitrag zur Vorgeschichte des deutschen Parlamentarismus (Lübeck and Hamburg, 1963), pp. 84f.

${ }^{40}$ Pollard, "Der unrevolutionäre Pionier", p. 34. 
early as 1867), the United Kingdom did not introduce it before 1918; the Reform Acts of 1867 and 1884 enfranchised only parts of the male working class. This restricted franchise, it is argued, made the English working class a calculable political factor that the Liberals nevertheless had to take into account. This double effect is considered a conditio sine qua non of the Gladstonian coalition. ${ }^{41}$

A variation on this argument is presented in an unpublished manuscript by Gustav Mayer who in the 1930s and 1940s, during his years of exile in London, compared English and German labour movements' strength with respect to the early 1860 s, i.e. with respect to the period before the introduction of universal suffrage in the North German Confederation. Focusing on the particular franchise of Prussia, Mayer comes to the conclusion that " $t]$ he existing electoral system favoured the English middle-class much less than the 'Dreiklassenwahlrecht' did the Prussian middle-class during the constitutional conflict with Bismarck". ${ }^{42}$

Only apparently do these interpretations agree with the mainstream Sonderweg explanation of the early formation of an independent workingclass party in Germany. While the Sonderweg concept focuses on the mobilizing effects of universal suffrage in Germany, the summarized explanations stress the absence in Germany of a "well-balanced" restricted franchise. However, this reservation does not mean that universal suffrage cannot explain anything. Werner Sombart, for example, assumes that it was probably a principal cause of the German labour movement's long-time concentration on political issues as well as of its relatively low opinion of trade unionism and co-operation. ${ }^{43}$ In this context, it should be mentioned that some years ago, Oxford historians, using statistical methods, confirmed the assumption that the growth of the English Labour Party was, among other reasons, limited by the franchise and a registration system

${ }^{41}$ For example, by Blackbourn and Eley, Mythen deutscher Geschichtsschreibung, p. 110; Geoff Eley, "Liberalismus 1860-1914. Deutschland und Großbritannien im Vergleich", in Dieter Langewiesche (ed.), Liberalismus im 19. Jahrhundert. Deutschland im europäischen Vergleich (Göttingen, 1988), pp. 272f. [hereafter, Liberalismus im 19. Jahrhundert]; also see Ira Katznelson, "Working-Class Formation and the State: Nineteenth-century England in American Perspective", in Peter B. Evans et al. (eds), Bringing the State Back in (Cambridge, MA, 1985), p. 273 [hereafter, "Working-Class Formation"]. For details about the franchise in the two countries, see Thomas T. Mackie and Richard Rose, The International Almanac of Electoral History (London, 1974).

${ }^{42}$ Gustav Mayer, The Political History of the English Labour Movement from 18571872: Documents and Commentaries, vol. 1, p. 6 (deposited in the archives of the London School of Economics, Coll. Misc. 355; the manuscript will be published in about 1990 by John Breuilly, Gottfried Niedhart and Tony Taylor). The same argument is developed by Breuilly, "Liberalismus oder Sozialdemokratie? Ein Vergleich der britischen und deutschen politischen Arbeiterbewegung zwischen 1850 und 1875", in Kocka, Europäische Arbeiterbewegungen, p. 150.

${ }^{43}$ See Sombart, "Dennoch!', pp. $48 f$. 
which excluded the greater part of the party's likely electoral support. Only when universal suffrage was finally introduced by the Representation of the People Act in 1918 did the Labour Party, according to this interpretation, achieve a political breakthrough. ${ }^{44}$

\section{Economic development}

Inasmuch as Sonderweg historians explain the differences between the English and German labour movements with reference to the economic development of the two countries they implicitly or explicitly refer to Alexander Gerschenkron's analysis of backward industrialization. ${ }^{45}$ According to this interpretation, the German variant of industrialization was not a piecemeal experiment like its English counterpart, but a revolution. The leading sectors of economic modernization in Germany, heavy industry and railways, were thought to have steamrollered the traditional sectors of the economy and rapidly eroded skills as well as craft traditions. In addition, they were thought to have subjected the labour force to a strict factory discipline from the start. Social Democracy as a mass party, the large-scale, highly bureaucratized trade-union movement, as well as the relative absence of occupational sectionalism in Germany appear, from this point of view, to be a result of the necessity for workers to bring the structure of their class organizations into line with the structure of the economic environment.

In the meantime, however, historical research has refuted this reductionist view. First of all, economic historians have heavily criticized Gerschenkron's concept in the last decade. They argue that, compared with other European countries, England's industrial development was not considerably advanced. With respect to the use of machinery and the percentage of the labour force working in factories, England did not show a breakthrough before the middle of the nineteenth century; this is exactly the same period that is regarded as the crucial one with respect to German industrialization. In addition, economic historians argue that the apparent backwardness of German industrialization when compared with England appears less distinctive than they had previously assumed, particularly if regional differences are taken into consideration. ${ }^{46}$

44 See H. C. G. Matthew et al. , "The Franchise Factor in the Rise of the Labour Party", English Historical Review, XCI (1976), pp. 723-752.

${ }^{45}$ See Alexander Gerschenkron, Economic Backwardness in Historical Perspective (Cambridge, MA, 1966).

${ }^{46}$ For a summary of the critique of Gerschenkron see P. K. O'Brien, "Do we Have a Typology for the Study of European Industrialization in the XIXth Century?", Journal of European Economic History, XV (1986), pp. 304ff. The implications for labour history are discussed by Eisenberg, Deutsche und englische Gewerkschaften, pp. 20ff.; 
Of course, economic historians refer to average data, and it cannot be denied that several branches of industry were in the formative period of the labour movement absolutely characterized by the presumed English/German differences. But it is striking that the Sonderweg correlation could not even be supported in a case study that refers to such a backward branch. Werner Berg's comparative research on mining in South Wales and the Ruhr Valley between 1850 and 1914 deals with a case that was undoubtedly characterized by small-scale enterprises on the British and by large-scale enterprises on the German side; this difference was largely caused by the German entrepreneurs' extraordinary need for capital engendered by technical problems (deep mining). But a correlation between large-scale enterprises and large-scale labour organizations cannot be observed in this particular case. According to Berg, the miners of slowly industrializing South Wales were indeed organized in a variety of small-scale unions and friendly societies, most of these being confined to the local level. However, the main characteristics of their Ruhr Valley colleagues was not the tendency to organize on a more general level but not to organize at all. Only from the 1890s onwards did Ruhr miners follow the Welsh example and organize stable trade unions that employers had to take seriously.$^{47}$

Berg does not explicitly discuss the possibility of generalizing from the results of his study. Nevertheless, he points to a crucial mistake in the logic of the Sonderweg correlation between the degree of industrial backwardness and the mode of labour organization: if industrialization is accelerated to make up for a country's relative backwardness it is usually accompanied by a high degree of regional mobility and fluctuation among the labour force. ${ }^{48}$ Although these factors allow large-scale and general forms of organisation to develop, it is evident that they primarily individualize workers and generally diminish their capacity for organization.

Another critique of the Sonderweg line of argument refers to the apparent correlation between industrial backwardness and the relative absence of occupational sectionalism in the German labour movement. This correlation cannot be verified either. As numerous social historians have emphasized in the last decade, the social basis of the German labour movement in the nineteenth century hardly suggests that it was one composed of an

also see Günther Lottes, "Der industrielle Aufbruch und die gesellschaftliche Integration der Arbeiterschaft in Deutschland und England im viktorianischen Zeitalter", in Adolf M. Birke and Kurt Kluxen (eds), Viktorianisches England in deutscher Perspektive (Munich, 1983), pp. 61ff.

${ }^{47}$ See Werner Berg, Wirtschaft und Gesellschaft in Deutschland und Großbritannien im Übergang zum 'organisierten Kapitalismus'. Unternehmer, Angestellte, Arbeiter und Staat im Steinkohlenbergbau des Ruhrgebietes und von Südwales, 1850-1914 (Berlin, 1984), pp. 290ff., 812ff.

48 Ibid., pp. 290-292. 
unskilled or semi-skilled labour force employed in railway construction or in the heavy industries. Quite the reverse: it was mainly composed of skilled workers occupied in the traditional sectors of German industry; in the formative phase artisans were most important. Therefore, as was the case in England (as well as in other European countries and the USA), wage differentials and conflicts deriving from the defence of narrow occupational interests were not absent from the rank and file of German labour organizations, nor could workers escape from the social impact of craft traditions. ${ }^{49}$ Nevertheless, in contrast to England these frictions hardly showed through at an organizational level in Germany.

In the end, differentials and boundary disputes between occupations may prove to have been more distinctive, the social impact of artisan traditions more direct in England than in Germany. But even if this assumption which has not up to now been verified ${ }^{50}$ - were to be confirmed by future research, it would not constitute a completely persuasive argument to explain fundamental differences in the character of the two countries' labour movements in terms of the gradual differences in the social composition of the labour forces. This is at least the position of social historians such as John Breuilly, who have attempted to examine the impact of the socalled labour aristocracy on the two countries' movements. ${ }^{51}$

${ }^{49}$ See P. D. Palmer, "Most Uncommon Common Men: Craft and Culture in Historical Perspective", Labour / Le Travailleur, I (1976), p. 14; William H. Sewell, Work and Revolution in France. The Language of Labour from the Old Regime to 1848 (Cambridge, MA, 1980), p. 1, and John Breuilly, "Artisan Economy, Artisan Politics, Artisan Ideology: the artisan contribution to the 19th century European labour movements", in Clive Emsley and James Walvin (eds), Artisans, Peasants and Proletarians, 1760-1860. Essays presented to Gwyn A. Williams (London, 1985), pp. 187-225. With particular reference to Germany: Jürgen Kocka, "Craft traditions and the labour movement in nineteenth-century Germany", in Pat Thane et al. (eds), The Power of the Past: Essays for Eric Hobsbawm (Cambridge, 1984), pp. 95-117.

${ }^{50}$ Some scattered evidence that can hardly be generalized is presented by Marc Linder, European Labor Aristocracies, pp. 206f. Also see Hartmut Kaelble, Industrialisierung und soziale Ungleichheit. Europa im 19. Jahrhundert. Eine Bilanz (Göttingen, 1983), ch. 3 , and the statistical data presented by Jürgen Kuczynski, Die Entwicklung der Lage der Arbeiter in Europa und Amerika 1870-1933. Statistische Studien zur Entwicklung der Reallöhne in England, Deutschland, USA, Frankreich und Belgien (Basel, 1934).

${ }^{51}$ Anyway, if there was an impact of the labour aristocracy at all, it was, according to their analyses, primarily due to the respective labour movements themselves. See John Breuilly's articles "The Labour Aristocracy in Britain and Germany: a Comparison", Bulletin of the Society for the Study of Labour History, XLVIII (1984), pp. 58-71, and "The Labour Aristocracy in Britain and Germany 1850-1914: A Review Article", in Tenfelde, Arbeiter und Arbeiterbewegung, pp. 179-226. Also see the older contributions to the debate by Peter N. Stearns, "The European Labor Movement and the Working Class, 1890-1914", in Harvey Mitchell and Peter N. Stearns (eds), The European Labor Movement, the Working Class and the Origins of Social Democracy 1890-1914 (Itasca/IL, 1971), pp. 143ff., and Robert Michels, "Psychologie der antikapitalistischen Massenbewegungen" (1926) and "Die oligarchischen Tendenzen der Gesellschaft. Ein Beitrag 
Since historians argue neither that the economic development in England and Germany was the same, nor that it was irrelevant to the shaping of the respective labour-movements' peculiarities, they are impelled to explore variables other than industrialization. The following argument proposes that a comparative analysis of the uneven development of capitalism might be a promising starting point. From this perspective some striking differences between the social structures of nineteenth-century England and Germany are revealed which up to now have seldom been discussed either by the promoters of the Sonderweg concept or by their critics. ${ }^{52}$

The groundwork for such an analysis has been prepared by Hermann Levy, an economic historian whose main writings were published in the first decades of the twentieth century, and by Jürgen Kuczynski, the Nestor of East-German Marxist labour historiography. Levy's Soziologische Studien über das englische Volk (1920) and Kuczynski's book The Rise of the Working Class (1967) continue the tradition of combining comparative economic and sociological analyses initiated by Lujo Brentano. As a common starting point they deal with a concomitant of the long tradition of capitalism in England: the extrernely early development of wage labour as demonstrated by the breakdown of the guild system from the sixteenth century and the emigration of peasants to the cities from the late seventeenth century onwards. From this perspective, they diagnose fundamental differences between the structure of both the middle and working classes in the two countries.

Kuczynski is primarily concerned with the working class. His analysis is based on the observation that about the middle of the nineteenth century, "(a)t a time when a working class was being formed in [. . . ] Germany, there was in England a working class of the second and third generation", an "hereditary proletariat". ${ }^{53}$ In contrast to England's advanced development, the social structure of continental countries, particularly of Germany, was characterized by "feudal barriers erected between grades and classes" which, according to Kuczynski, also affected the working class. ${ }^{54}$

zum Problem der Demokratie" (1908), reprinted in Robert Michels, Masse, Führer, Intellektuelle: Politisch-soziologische Aufsätze 1906-1933 (Frankfurt and New York, 1987), pp. 86, 145.

${ }^{52}$ An exception, although not writing from a comparative point of view, is Kocka, Lohnarbeit und Klassenbildung.

${ }_{53}$ Jürgen Kuczynski, The Rise of the Working Class (London, 1967), p. 145 [hereafter, The Rise of the Working Class]. The book was originally written in German (Das Entstehen der Arbeiterklasse (Munich, 1967) ) and translated into several other languages. Meanwhile the absence of a "born proletariat" in mid-nineteenth-century Germany has been demonstrated in a case study by Hartmut Zwahr, Die Konstituierung des Proletariats als Klasse. Strukturuntersuchungen über das Leipziger Proletariat während der Industriellen Revolution (2nd ed. Munich, 1981).

${ }^{54}$ Kuczynski, The Rise of the Working Class, p. 146. 
He refers to the miners, whose way of life before the middle of the nineteenth century was strictly regulated by the mining bureaucracies of several German states, and to servants and farm hands, who were subordinated to the Gesindeordnung. According to his analysis, artisans belonged to the pioneer strata of working-class formation in Germany, but a majority of them were still involved in "the stuffy atmosphere of semifeudalism" (Zunftdenken); therefore, they did not become aware of their class position. Thus Kuczynski concludes that until about the middle of the nineteenth century the German working class "was relatively small, a whole group of workers which in England and France formed part of it were missing". .55

Levy's comparative analysis of the English and German middle classes completes Kuczynski's interpretation. Anticipating some of the conclusions of more recent studies in the history of the European middle classes, he points to the fact that the English middle classes were in the nineteenth century comparatively disjointed. Not only did England lack an equivalent of the German Beamtenstand (civil service) and the Akademikerstand (academics), but, as a consequence of the relatively advanced development of capitalism, England also lacked the so-called Mittelstand, a distinctive subdivision composed of shopkeepers, self-employed artisans and peasants. In the nineteenth century, most of her artisans and peasants were proletarianized for a long time; the few remaining had completely lost their Standesbewußtsein (corporate consciousness) and were thoroughly individualized, just as the shopkeepers were. According to Levy this individualization was, among other factors, indicated by the absence in England of an equivalent of the Mittelstandsbewegung in Germany, i.e. a movement for maintaining and extending the influence of the Mittelstand upon economic life and policy. ${ }^{56}$

Both Kuczynski's and Levy's analyses of the impact of capitalism on the two countries' social structures are suited to explain the relative absence of occupational sectionalism from the German labour movement. Firstly, Kuczynski's diagnosis that the German working class, particularly in its formative phase, was comparatively incomplete and small, implies that it was also comparatively homogeneous. Secondly, as a consequence of the corporate subdivisions in the middle classes emphasized by Levy, the boundaries between the middle and the working classes seem to have been more marked in Germany than in England. Thirdly, Levy points to a unifying effect that has also been noticed by more recent research: the

${ }^{55}$ Ibid., pp. 207-213, quotation p. 213.

${ }^{56}$ See Hermann Levy, Soziologische Studien über das englische Volk (Jena, 1920), particularly p. 26 [hereafter, Soziologische Studien]; also see Geoffrey Crossick, "The Petite Bourgeoisie in Nineteenth-Century Europe: Problems and Research", in Tenfelde, Arbeiter und Arbeiterbewegung, pp. 259-261ff., 271ff. 
Mittelstandsbewegung attacked trade unions as well as workers' cooperatives and organized a social opposition towards the German labour movement that did not find a parallel in England. ${ }^{57}$

Apart from these general conclusions, these analyses seem to offer a quite promising explanation of further subtle differences between the rank and file of the English and German labour movements that have only recently been discussed by comparative labour historiography. The tendency of 'proletaroid' master artisans to join the labour movement was obviously less marked in Germany. ${ }^{58}$ On the other hand, white-collar workers seem to have been a less distinguished subgroup in England, where they individually floated between the working and the middle classes, than in Germany ${ }^{59}$ Perhaps, Kuczynski's and Levy's analyses may also explain why German social historians traditionally face fewer difficulties in distinguishing between Bürger and verbürgerlichte Arbeiter than their British colleagues who are devoting an increasing amount of their energies to the subtle differences between middle- and working-class "respectability". ${ }^{60}$

${ }^{57}$ See Levy, Soziologische Studien, pp. 6f. ; also see Christiane Eisenberg, "Il movimento cooperativo tedesco 1850-1914: fattori di sviluppo economici e sociopolitici", in Maurizio degl' Innocenti (ed.), Le imprese cooperative in Europa (Pisa, 1986), pp. 164ff., $171 \mathrm{f}$.

${ }_{58}$ See Eisenberg, Deutsche und englische Gewerkschaften, pp. 64ff. and the literature quoted there. Also see John Rule, "Artisan Attitudes: a Comparative Survey of Skilled Labour and Proletarianization Before 1848", in Bulletin of the Society for the Study of Labour History, L (1985), pp. 22f. (on the question "The artisan as middle class?"). It is no contradiction to this general observation if other scholars emphasize that there were small masters among the members of social democratic organizations and trade unions (see, for example, David Blackbourn, "Between resignation and volatility: the German petite bourgeoisie in the nineteenth century", in Geoffrey Crossick and Heinz-Gerhard Haupt (eds), Shopkeepers and Master Artisans in Nineteenth-Century Europe (London, 1984), p. 54). Apart from the fact that most of these studies deal with a later period, they generally do not take into consideration the fact that the percentage of small masters in the total labour force was considerably greater in nineteenth-century Germany than in England, where it was estimated to be about $5 \%$ in 1800 . See Adam Smith, The Wealth of Nations, ed. E. Cannan, 2 vols (London, 1904), 1, pp. 73-74, and L. D. Schwarz, "Income Distribution and Social Structure in London in the Late Eighteenth Century", Economic History Review, XXXII (1979), pp. 256-257.

${ }^{59}$ See the articles by Gregory Anderson, "Angestellte in England 1850 bis 1914", and Peter Behringer, "Ingenieure und Techniker. Technische Angestellte in Großbritannien im späten 19. und frühen 20. Jahrhundert", in Jürgen Kocka (ed.), Angestellte im europäischen Vergleich. Die Herausbildung angestellter Mittelschichten seit dem späten 19. Jahrhundert (Göttingen, 1981); see particularly Anderson's article, p. 70.

${ }^{60}$ For an overview of the dimensions of "respectability", see F. M. L. Thompson, The Rise of Respectable Society. A Social History of Victorian Britain 1830-1900 (London, 1988). Also see Levy, Soziologische Studien, pp. 54ff. 


\section{Pre-industrial traditions}

Inasmuch as the Sonderweg concept deals with the consequences for the German labour movement of so-called pre-industrial traditions, it primarily refers to the state and the bureaucracy. The social impact of these institutions is discussed with respect to the comparatively high degree of repression that the German labour movement faced in the nineteenth century (Vereins- and Koalitionsrecht; Sozialistengesetz); the bureaucracy is thought to have served as an organizational model for the trade union movement and the Social Democratic Party; and the intellectuals who flocked around the labour movement from its very beginnings are considered a primary reason for the high status of abstract ideologies such as Marxism. The English labour movement, on the other hand, is thought to have been excluded from the "necessity of violent overthrow of the state", as Peter Nettl puts it, "precisely because there was no state as such to overthrow". 61

Comparative labour historiography does not generally reject this line of interpretation, particularly since scholars emphasize the support of the bureaucracy for the survival of the particular German guild tradition, which is, for example, regarded as an important factor in explaining why German trade unionism, by and large, only rose from the late 1860 s onwards. ${ }^{62}$ But the Sonderweg interpretation has been indirectly qualified by American historians who point to the fact that the American labour movement developed quite differently from the English although both movements shared the experience of a "weak state" ${ }^{63}$ This may have contributed to the tendency of recent comparative research to focus primarily on pre-industrial traditions other than the state and bureaucracy.

The studies in the following presentation have in common that they emphasize a particular feature of the English labour movement which might be labelled, in the language of Anglo-American historiography, the "community tradition". A community (such as the family, peer groups, neighbourhoods, occupational groups, etc.) is considered to be "built on direct relationships", while its counterpart class "is made possible as a form of social solidarity only by the development of large-scale systems of

${ }^{61}$ Peter J. Nettl, "The State as a Conceptual Variable", World Politics, XX (1967-1968), p. 572. For a summary of the arguments, see Jürgen Kocka, "Vorindustrielle Faktoren in der deutschen Industrialisierung. Industriebürokratie und 'neuer Mittelstand' ', in Michael Stürmer (ed.), Das Kaiserliche Deutschland. Politik und Gesellschaft 1870-1918 (Düsseldorf, 1970), pp. 265-286; also see Kenneth H. F. Dyson, The State Tradition in Western Europe. A Study of an Idea and Institution (Oxford, 1980) [hereafter, The State Tradition].

${ }_{62}$ Eisenberg, Deutsche und englische Gewerkschaften, pp. 169-191.

${ }^{63}$ See Katznelson, "Working-Class Formation". 
indirect relationships. In Marxist theory in particular, class refers to social collectivities constructed not haphazardly on the local scene but at the level of the whole social formation . ..."64 Although the community school of labour historiography does not deny that there may be situations when communities support class formation, as E. P. Thompson has demonstrated with respect to Chartism in The Making of the English Working Class, it primarily considers the relationship between community and class as competitive. Thus the development of trade unionism and other working-class organizations, particularly of political parties, is generally not thought to reflect the strength of communal bonds between the workers, but their weakness. Scholars refer to the social anthropologist S. F. Nadel emphasizing that "mechanisms of association must make up for the loss of community character; techniques of communication will make the wide-range coordination of behaviour possible; and administrative machinery will enforce it; and idea systems will sustain the awareness of belonging together which can no longer spring from proximity and familiarity". ${ }^{65}$

Up to now the community approach to labour history has not explicitly offered a comprehensive interpretation of the English and German labour movements; however, research by numerous scholars fits together like a mosaic. A most interesting contribution has been presented by Ross McKibbin, a social historian who has also examined the rise of the Labour Party. His answer to the question "Why was there no Marxism in Great Britain?" is, amongst other things, based on the diagnosis that, in contrast to Germany, "a working class without an already established associational culture, one whose organizing energies [. . . ] could be utilized and directed by [. . . ] [a] party [ . . .] did not exist in Britain". ${ }^{66}$ Among the reasons that McKibbin gives to support his argument are several that point to concomitants of the early development of capitalism and wage labour in England. First of all, he emphasizes the early start and slow development of urbanization which made it possible for English workers to transfer memories of their rural past into urban life: sports, religious affiliations, and "millions of cottages in thousands of villages". Only in Scotland and in parts of London and Liverpool were the working classes, according to McKibbin, "herded

${ }^{64}$ Craig Calhoun, "Class, place and industrial revolution", in Nigel Thrift and Peter Williams (eds), Class and Space. The Making of Urban Society (London and New York, 1987), p. 51. For a more detailed definition and a critical examination of Toennies's dichotomy "Gemeinschaft und Gesellschaft" see the same author's article "Community: Towards a Variable Conceptualization for Comparative Research", Social History, V (1980), pp. 107-127 [hereafter, "Community"]. Also see David Crew, "Class and Community. Local Research on Working-Class History in Four Countries", in Tenfelde, Arbeiter und Arbeiterbewegung, pp. 279-336.

${ }^{65}$ S. F. Nadel, The Foundations of Social Anthropology (London, 1951), p. 154, quoted by Calhoun, "Community", p. 115.

${ }^{66}$ McKibbin, "Why is there no Marxism?", p. 306. 
continental-style into flats". He argues that "these souvenirs helped to familiarize a newish working class with industry, provide a comforting associational structure for urban life and diminish the catastrophic alienation which overtook much of an ex-peasant workforce on the Continent" ${ }^{67}$ Being able to unite by itself, the English working class did not need support from organizations and intellectuals. Quite the reverse, these were rejected to preserve the high degree of associational independence. ${ }^{68}$

Additional empirical evidence is given by scholars who have studied particular aspects of working-class everyday life. Thus Josef Ehmer has revealed that, as a rule, English artisans, journeymen as well as masters, were married. They lived in their own households and, from the late eighteenth century onwards, tended to make them the main unit of production; the juvenile labour force was generally recruited from the neighbourhood. In Germany and other Central European countries where guild laws remained influential, master artisans could, in contrast to England, maintain a monopoly on handicraft production to a high degree; even under the conditions of the putting-out system journeymen were, as a rule, not self-employed. Thus according to Ehmer, a high percentage of journeymen remained single and continuously mobile, and apprentices had generally to be recruited from rural areas. ${ }^{69}$ While the English pattern of artisan production facilitated the development of stable social relations among families, peer groups, neighbourhoods and - as other authors have also demonstrated $^{70}$ - on the shop floor, the Central-European pattern reinforced a tendency to individualization among journeymen, a core stratum of the rising labour movement.

${ }^{67}$ Ibid., pp. 306ff., quotation p. 307.

${ }^{68}$ Ibid., pp. 326f. McKibbin's assumptions about the status of community traditions among the English and German working class are fully supported by Werner Berg's comparative studies in mining. Berg unravels a village-like system of social relations among the miners of South Wales and an urban type in the Ruhr Valley. See his "Zwei Typen industriegesellschaftlicher Modernisierung: Die Bergarbeiter im Ruhrgebiet und in Südwales im 19. und frühen 20. Jahrhundert", in Gustav Schmidt (ed.), Bergbau in Großbritannien und im Ruhrgebiet. Studien zur vergleichenden Geschichte des Bergbaus 1850-1930 (Bochum, 1985), pp. 199-219 [hereafter, "Zwei Typen industriegesellschaftlicher Modernisierung"].

${ }^{69}$ See Josef Ehmer, "Master's Household or Journeyman's Family: The Units of Artisan Outwork Production in Central Europe and England in the Mid-19th Century". Paper for the ESRC Workshop on Proto-Industrial Communities, University of Essex, 31 October 1986; also see Ehmer's unpublished study "Das Heiratsverhalten und die Traditionen des Kapitalismus. England und Mitteleuropa im 19. Jahrhundert" (Habilitationsschrift, Vienna, 1988), ch. 3. I am grateful to Josef Ehmer for putting unpublished material at my disposal.

${ }^{70}$ See Eisenberg, Deutsche und englische Gewerkschaften, pp. 67-84. Also see for shop-floor relations the interesting study of Richard Gilbert Biernacki, Jr., "The Cultural Construction of Labor: A Comparative Study of Late Nineteenth-Century German and British Textile Mills" (Ph.D., University of Berkeley, CA, 1988). 
The consequence of this English particularity was the establishment of voluntary associations to protect the working-class family and shop-floor communities against the risks of life and the market. As British social historians have shown, friendly societies, cooperative and trade societies began to grow steadily in England from the eighteenth century onwards, many of them being supported by nonconformist sects that formed close parish communities apart from the Anglican Church. Thus a dense network of voluntary associations for material purposes had long been in existence when the trade-union movement began to amalgamate into large-scale organizations from about the middle of the nineteenth century onwards. ${ }^{71}$

In contrast to the English development, working-class communities based on economic self-help were largely absent from pre-industrial Germany. With few exceptions, they developed only with the rise of the Social Democratic Party, many of them being founded by party functionaries. ${ }^{72}$ From the turn of the century the Protestant and Catholic Churches also took the opportunity to establish cooperatives and trade societies. But societies for sociability and general education, which had also dominated before the rise of the labour movement, remained the prevailing type of voluntary association among German workers for decades. As Werner Berg rightly emphasizes in his comparative studies in mining, these societies can be regarded as efforts to artificially establish community traditions. The comparatively high degree of regional mobility that Berg diagnoses even among the miners of the Ruhr area, made middle-class support, formal organization, and, as a consequence, a certain anonymity, indispensable preconditions of their stability. ${ }^{73}$

The comparatively high standard of living that can at least partly be considered an effect of the long tradition of trade unionism and cooperation in England, prepared the ground for another variant of community life. As McKibbin argues, it "did permit more or less everything that made up late-nineteenth-century working-class pastimes: the development of organized hobbies, mass sport, popular betting, a modest domesticity and the commercialization of much working-class entertainment. They gave the working classes a certain autonomy, an opportunity to choose between

${ }^{71}$ See P. H. J. H. Gosden, Self-Help. Voluntary Associations in 19th Century Britain (New York, 1974), and Adolf M. Birke, "Voluntary Associations. Aspekte gesellschaftlicher Selbstorganisation im frühindustriellen England", in Gesellschaftliche Strukturen als Verfassungsproblem. Intermediäre Gewalten, Assoziationen, öffentliche Körperschaften im 18. und 19. Jahrhundert (Berlin, 1978), pp. 79-91. The most detailed study on the activities of religious sects is Stephen Yeo, Religion and Voluntary Organizations in Crisis (London, 1976).

72 For a comparative statistical overview, see Eisenberg, "Arbeiter, Bürger und der 'bürgerliche Verein' ", pp. 198-202.

${ }^{73}$ Berg, "Zwei Typen industriegesellschaftlicher Modernisierung”, p. 212. For a similar argument, see Eisenberg, Deutsche und englische Gewerkschaften, pp. 113-115. 
alternative activities not available to any other European workforce [ . . ]. The result was that any working-class party had to compete with an existing working-class culture which was stable and relatively sophisticated."74

A complementary interpretation is suggested from the German point of view. Like the English workers, German workers hardly participated in the cultural activities of the middle classes; they lacked time and money and were often intentionally excluded. In addition, mass sports and a commercialized mass-culture achieved a breakthrough in Germany only after World War I. Therefore, with respect to the organization of workers' leisure time, the rising labour movement could occupy a vacuum. The Social Democratic Party and, from the turn of the century onwards, the Christian (Catholic) trade-union movement, quite successfully ran chess, ramblers', theatre, and other societies and politicized them from the start. Thus compared with its English equivalent, the culture of the German working class appears to a high degree identical with the culture of the labour movement, as numerous historians have emphasized in the last few years. ${ }^{75}$

These arguments agree with the interpretations of the organizational structure of the German labour movement presented by Werner Sombart as well as by more recent scholars such as Detlef Lehnert or Mary Nolan. In contrast to Sonderweg authors, they do not primarily consider party and trade-union bureaucracies as corollaries of the particular German state tradition but emphasize their positive functions in the process of class formation. Since the German workers, compared with their English colleagues, were an "utterly shapeless mass" (Sombart), formal organization, as well as ideologies and leading figures, were indispensable preconditions to get and keep the process of class formation going. While in early nineteenth-century England the working class could eventually "make itself", as E. P. Thompson has argued, according to these authors the

${ }^{74}$ McKibbin, "Why is there no Marxism?", p. 307.

${ }^{75}$ See W. L. Guttsman, The German Social Democratic Party, 1875-1933: From Ghetto to Government (London, 1981), p. 208; Dick Geary, "Arbeiterkultur im Deutschland und Großbritannien im Vergleich”, in Dietmar Petzina (ed.), Fahnen, Fäuste, Körper. Symbolik und Kultur der Arbeiterbewegung (Essen, 1986), pp. 91-99, 138-139 (a shortened English version is in Roger Fletcher (ed.), Bernstein to Brandt. A Short History of German Social Democracy (London, 1987)), and Friedhelm Boll, "Vergleichende Aspekte europäischer Arbeiterkulturen”, in Friedhelm Boll (ed.), Arbeiterkulturen zwischen Alltag und Politik. Beiträge zum europäischen Vergleich in der Zwischenkriegszeit (Vienna, 1986), p. 13; also see Gerhard A. Ritter, "Probleme der Erforschung von Arbeiterschaft und Arbeiterbewegung in Deutschland vom Ende des 18. Jahrhunderts bis zum Ersten Weltkrieg", Tel Aviver Jahrbuch für deutsche Geschichte, XVI (1987), p. 387 and the literature cited there. 
German working class appeared to a considerably higher degree dependent on "being made" from the outside. ${ }^{76}$

\section{Conclusion}

Comparisons provide a rough negative check on accepted historical interpretations and a tool for criticizing and invalidating mistaken theoretical assumptions. As this article demonstrates, such a function has been served by English and German labour historiography. The summarized comparative studies have contributed to a rejection of some fundamental arguments of the Sonderweg interpretation, among them several well-established assumptions about the relationship between the working and the middle classes and about the social impact of industrial backwardness. In addition they have corrected those Sonderweg arguments that refer to the constitutional frameworks of the English and German labour movements. And by pointing to the consequences for the working classes of the different timing of capitalism in the two countries, they have added a new complexion to the debate.

But the comparative method should not be overused. Seen as a whole, the summarized studies may support those historians who prefer to speak about "the peculiarities of the English" instead of a "Deutscher Sonderweg". ${ }^{77}$ However, they are no substitute for a new, comprehensive interpretation which has to be brought in from outside. ${ }^{78}$ Building such an

${ }^{76}$ Sombart, Der proletarische Sozialismus, 2, pp. 368f., 386; the quotation is from p. 368. Also see Mary Nolan, Social Democracy and Society. Working-class Radicalism in Düsseldorf 1890-1920 (Cambridge, 1981), p. 223: "[T]he Social Democrats not only created a powerful movement but a working class as well." For a summary of her interpretation, see her "Economic Crisis, State Policy, and Working-Class Formation in Germany, 1870-1900", in Ira Katznelson and Aristide R. Zolberg (eds), Working-Class Formation. Nineteenth-Century Patterns in Western Europe and the United States (Princeton, 1986), pp. 352-393. The nexus between fluctuation and bureaucratic organization in German Social Democracy is emphasized by Detlef Lehnert, "Zur politischen Transformation der deutschen Sozialdemokratie. Ein Interpretationsversuch für die Zeit des Übergangs zum Organisierten Kapitalismus", in Jürgen Bergmann et al. (eds), Geschichte als politische Wissenschaft. Sozialökonomische Ansätze, Analyse politikhistorischer Phänomene, politologische Fragestellungen in der Geschichte (Stuttgart, 1979), pp. 304ff., particularly the statistics on p. 306.

${ }^{7}$ See, for example, Alan Macfarlane, "Socio-economic Revolution in England and the Origin of the Modern World", in Roy Porter and Mikulas Teich (eds), Revolution in History (Cambridge, 1986), pp. 145-166, and Hans-Christoph Schröder, "Der englische 'Sonderweg' im 17. und 18. Jahrhundert", in Karl-Ernst Jeismann and Hanna Schissler (eds), Englische und deutsche Geschichte in den Schulbüchern der beiden Länder. Wahrnehmungsmuster und Urteilsstrukturen in Darstellungen zur neueren Geschichte (Braunschweig, 1982), pp. 27-35.

${ }_{78}$ This is the argument of Theda Skocpol and Margaret Somers, "The Uses of Comparative History in Macrosocial Inquiry", Comparative Studies in Society and History, XXII (1980), pp. 174-197. 
interpretation is the business of future discussion. It is therefore incumbent upon us to revert to Sonderweg historians' initial matter of concern, i.e. to develop a comprehensive and coherent interpretation of the German Kaiserreich, and German labour history in particular, which can withstand international comparisons.

With respect to this latter demand, one topic for research that seems quite promising should again be emphasized: the relative absence of a stable community structure dating from pre-industrial times among nineteenth-century German workers. This particular feature of German social history has not only been considered a problem by recent labour research; comparative historical research on liberalism has discussed it as well, coming to the conclusion that German liberalism faced comparatively unfavourable starting conditions: while English liberals could seek to attract the cooperation of numerous pre-existing societies for material and religious purposes, German liberals, lacking these reinforcements, had to encourage beforehand and to institute the so-called Vereinswesen. They had to do this themselves - or with the help of the bureaucracy. ${ }^{79}$

Taken together, these results of comparative research suggest that a future interpretation of German history should take the following into consideration. If the labour movement and liberalism, i.e. those political forces that were most likely to break up the authoritarian power structures of the German Kaiserreich, were scarcely supported by established communities, the persistence of those structures cannot alone be considered a cause of the failure of democracy in Germany. This persistence also seems to be a consequence of the unfavourable developmental conditions for the growth of a "democracy from below". This interpretation, taking into consideration the relative backwardness in Germany of community-building processes, such as the development of capitalism, wage labour and market relations, ${ }^{80}$ can be supported by the following observations.

Firstly, a recent book by John Saville about the attitude of the English state towards the labour movement raises doubts as to whether the willingness of the state to repress democracy was really more marked in nineteenth-century Germany than in England. ${ }^{81}$ Perhaps it was only the Ger-

79 See Rolf Muhs, "Deutscher und britischer Liberalismus im Vergleich. Trägerschichten, Zielvorstellungen und Rahmenbedingungen (ca. 1830-1870)", in Langewiesche, Liberalismus im 19. Jahrhundert, pp. 242ff.; Dieter Langewiesche, "Liberalismus und Bürgertum in Europa", in Kocka, Bürgertum im 19. Jahrhundert, 3, p. 370, and Reulekke, "Formen bürgerlich-sozialen Engagements", p. 278.

${ }^{80}$ About the contribution to community-building of these processes see Max Weber, Wirtschaft und Gesellschaft. Grundriß der verstehenden Soziologie (5th revised ed., Tübingen, 1976), pp. 382-384.

${ }^{81}$ See John Saville, 1848. The British State and the Chartist Movement (Cambridge, 1987). 
man state's ability to suppress that was greater: experience shows that it is easier to paralyze large-scale organizations such as political parties than to fight against small, scattered communities.

Secondly, historians should ask whether capitalism did finally succeed in making up for the relative lack of community traditions among German workers, when economic and social modernization broke through old barriers from the late nineteenth century onwards. This is not only doubtful because of the increase of regional and social mobility which accompanied an accelerated process of modernization; it is also doubtful because the German "modernization from above" might have further retarded the development of communities. This assumption has been supported, for example, by comparative research on the rise of the welfare state in the two countries. Social welfare provided by the state seems to have met a greater demand as well as less resistance in Germany than in England, since private self-help was comparatively less marked and grew only slowly. ${ }^{82}$ Similar developments can be observed in other fields of labour politics. For example, from 1896 onwards, vocational schools for apprentices became compulsory in Germany. They were suited to undermining the authority of the instructors on the shop floor and thus to weaken their capacity to integrate apprentices into workshop communities.$^{83} \mathrm{~A}$ final example is suggested by the fact that the relative backwardness and the weak labour-market position of early German trade unions led labour leaders to foster the regulation of industrial relations by law. In the long run this strategy seems to have undermined the willingness of workers to organize. The free-rider problem became evident from 1918 at the latest, when, as a consequence of the revolution, wage agreements and, to a limited degree, co-determination on the shop floor were guaranteed to all workers, not exclusively to unionists. ${ }^{84}$

Thus it may be argued that the activities of the state, and in many cases the politics of the German labour movement itself, tended to undermine the social bases of the new communities which developed with capitalism;

82 See Gerhard A. Ritter, "Soziale Sicherheit in Deutschland und Großbritannien von der Mitte des 19. Jahrhunderts bis zum Ersten Weltkrieg. Ein Vergleich", Geschichte und Gesellschaft, XIII (1987), pp. 137-156. For a more detailed English version, see his Social Welfare in Germany and Britain. Origins and Development (Leamington Spa, 1986).

${ }^{83}$ See Rolf Schöfer, Berufsausbildung und Gewerbepolitik. Geschichte der Ausbildung in Deutschland (Frankfurt, 1981). Although not indicated by the title, this study is based on an English/German comparison.

${ }^{84}$ For a comparative perspective on the legal regulation of collective bargaining in England and Germany, see Walther Müller-Jentsch, "Versuch über die Tarifautonomie. Entstehung und Funktionen kollektiver Verhandlungssysteme in Großbritannien und Deutschland", Leviathan, XI (1983), pp. 118-150, and Spiros Simitis, "Zur Verrechtlichung von Arbeitsbeziehungen", in Friedrich Kübler et al. (eds), Verrechtlichung von Wirtschaft, Arbeit und sozialer Solidarität (Frankfurt, 1984), pp. 73-167. 
they might have done so, before these communities were really established. ${ }^{85}$ On these assumptions, the German path into modernity, whether it is called a Sonderweg or not, generated a dynamic that was probably unstoppable.

${ }^{85}$ Such an interpretation would be compatible with the diagnosis of late nineteenth- and early twentieth-century conservative intellectuals, who considered the absence of $G e$ meinschaft a peculiarity of German society. However, historians could hardly take serious their slogan Zurück zur Gemeinschaft. For a survey, see Theodor Geiger, "Gemeinschaft", in Alfred Vierkandt (ed.), Handwörterbuch der Soziologie (Stuttgart, 1931), particularly p. 175. For the absence in England of such a debate, see Dyson, The State Tradition, p. 56. 